\title{
TINJAUAN KOMPILASI HUKUM ISLAM PASAL 53 TENTANG PERNIKAHAN WANITA HAMIL DI LUAR NIKAH
}

\author{
Hariyono \\ Anwarudin \\ Universitas Nahdlatul Ulama Surakarta
}

\begin{abstract}
Abstrak
Tulisan ini bertujuan untuk mengetahui pelaksanaan perkawinan wanita yang telah hamil dan belum hamil dan ditinjau dalam hukum Islam. Jenis penelitian ini adalah penelitian kualitatif. Pendekatan yang ditempuh dalam penelitian ini adalah pendekatan yuridis-normatif-sosiologis. Pelaksanaan pernikahan wanita hamil yang terjadi di KUA Kecamatan Masaran Sragen Tahun 2017 adalah sama dengan ketentuan pernikahan pada umumnya atau pada mestinya, sehingga tidak ada perbedaan antara pelaksanaan pernikahan wanita yang telah hamil dengan pernikahan waniya yang belum hamil. Pasal 53 Kompilasi Hukum Islam tentang Pernikahan Wanita Hamil di Luar Nikah ini membolehkan pernikahan wanita hamil tersebut.
\end{abstract}

Kata kunci: Kompilasi Hukum Islam, Perkawinan, Kehamilan

\section{Abstract.}

This article aims to find out the implementation of marriages of women who have been married and have not been pregnant and reviewed in Islamic law. This type of research is qualitative research. The approach taken in this study is a juridical-normatif-sociological approach. The implementation of pregnant women's marriages that occurred in the Kua District Masaran Sragen in 2017 is the same as the provisions of marriage in general or should be, so there is no difference between the implementation of marriage of women who have become pregnant and waniya marriage who are not 
pregnant. Article 53 compilation of Islamic law on the marriage of pregnant women out of wedlock allows the marriage of pregnant women.

Keywords: Compilation of Islamic Law, Marriage, Pregnancy

\section{A. PENDAhuluan.}

Manusia adalah makhluk sosial yang tak dapat hidup seorang diri. Manusia perlu menjalin hubungan dengan orang lain, baik itu dalam kehidupan masyarakat maupun berumah tangga. Sehingga bagi manusia melakukan perkawinan merupakan kebutuhan yang penting, agar seseorang dapat berinteraksi dengan orang lain dan dapat menyalurkan kebutuhan biologis mereka. Nikah berasal dari bahasa arab yang berarti sekumpulan, bisa juga diartikan perikatan atau persetubuhan.'

Dewasa ini, dengan berkembangnya teknologi yang begitu cepat. Telah memberikan dampak positif akan arti dari kemajuan itu sendiri. Akan tetapi pada sisi lain dampak negatifnya tidak bisa dihindari. Dan ini merupakan dilema dari dampak kemajuan peradaban manusia.

Salah satu pengaruhnya adalah cara hidup masyarakat yang kini mulai mengarah pada pergaulan bebas. Pergaulan bebas sangat identic dengan free sex (zina) yang sudah menghawatirkan. Inilah yang menyebabkan tingkat kehamilan pranikah terus meningkat dari tahun ke tahun. Bahkan perilaku free sex telah terjadi pada generasi muda yang masih belia.

Fenomena lahirnya anak diluar nikah banyak dipengaruhi oleh adanya trend pergaulan bebas atau perilaku seks pranikah dikalangan remaja. Berdasarkan data dari beberapa lembaga survei di Indonesia, yang menyebutkan antara lain:

1. Data survei tahun 2016 Komnas Anak di 12 Provinsi di Indonesia menyebutkan bahwa dari 4.500 remaja sebagai responden didapatkan data:

a. 93,7 \% pernah berciuman hingga petting (bercumbu)

b. $62,7 \%$ remaja SMP sudah tidak perawan

\footnotetext{
${ }^{1}$ Mahmud Yunus, Kamus Bahasa Arab-Indonesia, (Jakarta: Hidakarya Agung, 1990), hal. 467
} 
c. 21,2 remaja SMA pernah aborsi.

2. Data survei Komisi Perlindungan Anak Indonesia (KPAI) didapatkan data:

a. $32 \%$ remaja 14-18 tahun pernah berhubungan seks,

b. $21,2 \%$ remaja putri pernah melakukan aborsi,

c. $97 \%$ penyebab remaja melakukan seks yaitu internet. ${ }^{2}$

Data survei diatas menunjukkan betapa persoalan sosial dan perilaku seks bebas di Indonesia sudah sangat memprihatinkan. Pengaruh arus informasi yang tidak dapat dibendung melalui media informasi internet memang menjadi ancaman berat bagi pemerintah dan para orangtua untuk bisa mengendalikan anak-anaknya agar terbebas dari dampak negatif pergaulan bebas. Dari beberapa faktor yang dapat memicu tingginya tingkat kelahiran anak diluar nikah, faktor pergaulan seks bebas menjadi faktor yang dominan, karena para remaja pada umumnya tidak memahami apa dampak yang akan ditimbulkan dari perilaku seks bebas yang dilakukannya, sehingga pada saat terjadi kehamilan, mereka dalam posisi yang tidak siap untuk menghadapinya, baik untuk melangsungkan perkawinan maupun untuk menjadi orang tua bagi si anak. Kemudian jika dilihat dari sudut pandang psikologis, kehamilan pranikah telah menjadi aib bagi keluarga. Sehingga sering terjadi orang tua berupaya untuk menikahkan anak putrinya yang hamil itu dengan laki-laki yang menghamilinya atau dengan pria lain, sehingga cucunya lahir ada ayahnya.

Islam sangat menjunjung tinggi kesucian diri dari bahaya dosa maupun efek yang mengganggu secara jasmani atas pelanggaran terhadap syariat. Dan perbuatan zina adalah pelanggaran yang mencakup hal-hal di atas. Maka Allah SWT dalam Al-Qur'an melarang dengan keras perilaku zina, sampai untuk mendekatinya saja telah mendapat larangan yang tegas.

Bentuk dari ketidakridhaan Allah SWT. Terhadap hambaNya yang beriman berbuat zina. Islam memang menganjurkan kepada setiap manusia untuk melaksanakan perkawinan (pernikahan), mencari pasangan hidup dan memperbanyak keturunan. Perkawinan merupakan ikatan suci antara seorang

2 D.Y. Witanto, Hukum Keluarga Hak dan Kedudukan Anak Luar Kawin, (Jakarta: Prestasi Pustaka, 2012), hal.16. 
laki-laki dengan seorang wanita untuk membentuk rumah tangga yang penuh ketentraman, kebahagiaan yang dipenuhi dengan kasih sayang dan didasari oleh nilai-nilai ajaran Islam.

Hubungan antara laki-laki dan perempuan diatur secara hormat danberdasarkan saling meridhoi dengan dilangsungkannya upacara perkawinan. Pernikahan menjadikan proses keberlangsungan hidup manusia di dunia iniberlanjut, dari generasi ke generasi. Selain itu juga untuk menyalurkan nafsu birahi yang dimiliki manusia sebagai makhluk Allah. Dengan pernikahan akan terhindar dari perbuatan yang dilarang oleh agama, seperti halnya sex bebas (freesex), prostitusi dan lain sebagainya. Sebab dengan cara pernikahan maka akanlebih efektif dan efisien untuk mencegah dan menghindari perbuatan zina.

Terkait dengan masalah menikah wanita hamil karena zina serta permasalahan yang terkait dengannya. Hal ini merupakan upaya penulis untuk ikut serta dalam upaya memelihara martabat dan identitas manusia sebagai makhluk terbaik ciptaan Allah yang beradab dan bermartabat. Semoga Allah SWT. selalu memberi petunjuk dan melapangkan usaha ini. Penulis yakin karena Islam dengan toleransi dan kesempurnaan ajarannya, keluhurannya dan komprehensifitas nilainya tidak akan meninggalkan suatu permasalahan kemanusiaan tanpa memberikan jalan keluarnya. Tidak ada kedustaan di dalamnya karena Islam adalah agama Allah yang lurus.

Peranan keluarga sangat dibutuhkan dalam pendidikan akhlak anakanaknya, terutama remajanya. Hal-hal yang terkandung di dalam pasal 53 Kompilasi Hukum Islam, diawali dengan kehidupan laki-laki dan wanita yang saling mengenal yang terambisi oleh nafsu setan hingga pergaulan bebas terjadi dan menyebabkan kehamilan bagi remaja putri atau wanitanya merupakan fenomena yang memalukan dalam kehidupan ini.

Dalam Instruksi Presiden No. 1 Tahun 1991 tentang penyebarluasan Kompilasi Hukum Islam (KHI), Bab VIII Kawin Hamil sama dengan persoalan menikahkan wanita hamil. Pasal 53 dari Bab tersebut berisi tiga (3) ayat, yaitu:

1. Seorang wanita hamil di luar nikah, dapat dinikahkan dengan pria yang menghamilinya. 
2. Perkawinan dengan wanita hamil yang disebut pada ayat (1) dapat dilangsungkan tanpa menunggu lebih dulu kelahiran anaknya.

3. Dengan dilangsungkan perkawinan pada saat wanita hamil, tidak diperlukan perkawinan ulang setelah anak yang dikandung lahir. ${ }^{3}$

Menurut Kompilasi Hukum Islam (KHI), kawin hamil diletakkan pada kategori hukum boleh, tidak mesti seperti yang dianut oleh kehidupan berdasar hukum adat. Memang, pendefinisian kebolehan kawin hamil yang diatur dalam KHI, sedikit banyak beranjak dari pendekatan kompromistik dengan hukum adat. Pengkompromian ini dilakukan karena mengingat memang realitanya dalam fiqih masalah ini menjadi ikhtilaf, di samping mempertimbangkan faktor sosiologis dan psikologis. Dari berbagai faktor inilah kemudian ditarik suatu kesimpulan berdasar asas istislah. Sehingga, tim perumus KHI berpendapat lebih besar maslahat membolehkan kawin hamil daripada melarangnya, tentunya dengan berberapa persyaratan tertentu. ${ }^{4}$

Masalah nikah dengan perempuan hamil di luar nikah akibat zina memerlukan ketelitian dan perhatian yang bijaksana bagi Pegawai Pencatat Nikah. Hal ini disebabkan semakin longgarnya norma-norma moral dan etika sebagian masyarakat, terlebih mereka yang masih remaja dan kesadaran keagamaannya labil.

Berdasarkan pengamatan yang dilakukan, Kecamatan Masaran Sragen sebagaidaerah yang masih kental dengan kebudayan jawa serta kebudayaan santri yakini semakin hari semakin pudar dengan pengaruh budaya globalisasi yang sudah merasuki pedesaan. Indikasi ini dapat dilihat dengan semakin menggejalanya kawin hamil yang terjadi di wilayah Masaran. Ironisnya kehamilan di luar nikah ini sering tejadi, kadang mereka tidak memandang hal itu sebagai pelanggaran yang merupakan aib dan kebejatan moral yang perlu dibenahi.

Tingginya kasus pernikahan wanita hamil yang terjadi di wilayah Kecamatan Masaran yang tercatat di Kantor Urusan Agama Kec. Masaran dari tahun ke tahun terus meningkat. Dari data yang kami dapat dari arsip

3 Dirjen Bimas Islam RI, Himpunan Peraturan Perundang-Undangan Perkawinan,(Jakarta: Depag, 2010), hal. 245.

${ }_{4}$ M. Yahya Harahap, Peradilan Agama dan Kompilasi Hukum Islam Dalam Tata Hukum Indonesia, (Yogyakarta: UII Press, 1993), hal. 85. 
berkas pemeriksaan nikah model NB pernikahan wanita hamil di KUA Kec. Masaran tahun 2017 yaitu bulan Februari ada 1 kasus dan bulan Maret dan April ada 2 kasus.

Nikah menurut bahasa mempunyai arti sebenarnya (haqiqat) dan artikiasan (majas). Arti yang sebenarnya dari nikah adalah "al-dammu" yang berarti menghimpit, menindih atau berkumpul. Sedangkan arti kiasan nikah adalah "wati" yang berarti setubuh atau aqad yang berarti mengadakan perjanjian pernikahan. Dalam masalah perkawinan, para ahli fiqh mengartikan nikah menurut kiasan. ${ }^{5}$

Beberapa penulis juga terkadang menyebut pernikahan dengan kata perkawinan, yang menurut bahasa, artinya membentuk keluarga dengan lawan jenis, melakukan hubungan kelamin atau bersetubuh, istilah "kawin" digunakan secara umum, untuk tumbuhan, hewan, dan manusia, dan menunjukkan proses generatif secara alami. ${ }^{\circ}$

Dijelaskan lain bahwa, lafadz nikah mengandung tiga macam arti yaitu, yang pertama arti menurut bahasa, dan yang kedua menurut ahli Ushul. Pertama: arti nikah menurut bahasa adalah berkumpul atau menindas (arti menindas dalam kamus bahasa Indonesia adalah menindih). Kedua: arti nikah menurut ahli ushul, terdapat tiga macam pendapat:

Pendapat pertama, nikah menurut arti aslinya ialah setubuh dan menurut arti majazi (metaphoric) ialah aqad yang dengannya menjadi halal hubungan kelamin antara pria dan wanita. Demikian menurut ahli ushul golongan Hanafi. Pendapat kedua, nikah menurut aslinya ialah aqad yang dengannya menjadi halal hubungan kelamin antara pria dan wanita, sedangkan menurut arti majazi ialah setubuh. Demikian menurut ahli ushul golongan Syafi'i. Pendapat ketiga, nikah, bersyarikat artinya antara aqad dan setubuh. Demikian menurut Abul-Qasim Azzadjdjad, Imam Yahya, Ibnu Hazm dan sebagian Ahli Ushul dari sahabat Abu Hanifah.' Sedangkan pengertian pernikahan/ perkawinan dalam Undang-undang No.1 tahun 1974 pasal 1 menyatakan bahwa perkawinan ialah ikatan lahir batin antara seorang pria dengan seorang wanita sebagai suami istri dengan tujuan membentuk

\footnotetext{
${ }^{5}$ Kamal Mukhtar, Asas-asas Hukum Islam Tentang Perkawinan, (Jakarta: Bulan Bintang, 1993), hal. 1

${ }^{6}$ At-Tihami, M.A, dan Sohari Sahrani, Fikih Munakahat Kajian Fikih Lengkap, (Jakarta: Raja Wali Pers, 2008), hal. 7.

${ }^{7}$ Ibrahim Hosen, Fiqh Perbandingan, (Jakarta: Ihya Ulumiddin Indonesia, 1971), hal. 65.
} 
keluarga (rumah tangga) yang bahagia dan kekal berdasarkan Ketuhanan Yang Maha Esa. ${ }^{8}$

Lebih dapat memahaminya arti nikah, maka para ulama mazhab juga sepakat bahwa nikah itu sah bila dilakukan dengan menggunakan redaksi زوجت (aku mengawinkan) atau انكحت (aku menikahkan) dari pihak yang dilamar atau orang yang mewakilinya dan redaksi qobiltu (aku terima) atau raditu (aku setuju) dari pihak yang melamar atau orang yang mewakilinya. ${ }^{9}$

Para ulama bersepakat bahwa nikah merupakan syari'at Islam yang tidak boleh diabaikan. Allah telah memuliakan bani Adam dan menjadikan nikah ini sebagai cara untuk memiliki keturunan di antara mereka. Untuk memelihara keturunan ini, Allah menetapkan sanksi zina dan menjadikannya seberat-beratnya sanksi sebab zina bukanlah cara tepat untuk membina keturunan dan menjaga keharmonisan bani Adam..$^{10}$ Berbagai pengertian tentang pernikahan dari berbagai ulama dan para pemikir Islam, dapat memudahkan kita mengetahui hakikat pernikahan. Memberikan wawasan baru dan tidak salah mengartikan tentang nikah.

Setelah kita memahami pengertian nikah, bahasan selanjutnya yaitu hukum perikahan. Akan tetapi sebelum kepada pengertian hukum pernikahan atau memahami hukum pernikahan, maka harus dipahami terlebih dahulu tentang tujuan daripada hukum Islam mengatur persoalan ini, yakni tujuannya adalah merealisasikan dan melindungi kemaslahatan umat manusia, baik kemaslahatan individu maupun masyarakat."

Hukum Islam atau sering disebut dengan syari'at, jika diartikan makna asalnya adalah jalan ke sumber (mata) air dan tempat orang-orang minum, atau jalan yang lurus (attariqat al-mustaqimat) yakni jalan yang dengan mudah dapat mengantarkan seseorang ke tempat yang ia tuju. Dan, Hukum Islam atau Syari'at yang kita yakini tertuang di dalam al-Qur'an dan

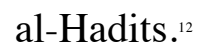

\footnotetext{
${ }^{8}$ Soemiyati, Hukum Perkawinan Islam dan Undang-Undang Perkawinan, (Yogyakarta: Liberty, 1982), hal. 9.

${ }^{9}$ Muhammad Jawad Mughniyah, Fiqh Lima Mahzab, (Jakarta: Lentera, 2007), hal. 309.

10 Taufik Rahman, Hadis-Hadis Hukum, (Bandung: Pustaka Setia, 2000), hal. 83.

${ }^{11}$ Said Agil Husin al-Munawar, Hukum Islam, (Jakarta: Penamadani, 2005), hal. 19.

${ }^{12}$ Mawardi Labay el-Sulthani, Tidak Usah Takut Syari'at Islam, (Jakarta: Al Mawardi Prima, 2002), hal. 43.
} 
Ulama ushul fiqh, baik klasik maupun kontemporer sepakat bahwa al-Qur'an dan al-Sunnah merupakan sumber Hukum Islam yang utama. Selain itu al-Qur'an dan al-Sunnah juga disebut sebagai dalil Hukum, artinya baik ayat-ayat al-Qur'an maupun hadits-hadits Nabi SAW disamping sebagai sumber Hukum Islam juga merupakan dalil (alasan dalam penetapan Hukum) ${ }^{13}$

Hukum nikah (pernikahan), hukum yang mengatur hubungan antara manusia dengan sesamanya yang menyangkut penyaluran kebutuhan biologis antar jenis, dan hak serta kewajiban yang berhubungan dengan akibat pernikahan tersebut.

Tujuan pernikahan dalam Islam adalah untuk memenuhi tuntutan hajat tabiat kemanusiaan, berhubungan antara laki-laki dan perempuan dlam rangka mewujudkan suatu keluarga yang bahagia dengan dasar cinta dan kasih sayang, untuk memperoleh keturunan yang sah dalam masyarakat dengan mengikuti ketentuan-ketentuan yang telah diatur oleh Syari'ah. ${ }^{14}$

Tihami dalam bukunya Fikih Munakahat yang dikutip dari Zakiyah dkk. Mengemukakan lima tujuan dalam perkawinan/pernikahan, yaitu:

1. Mendapatkan dan melangsungkan keturunan,

2. Memenuhi hajat manusia menyalurkan syahwatnya dan menumpahkan kasih sayangnya,

3. Memenuhi panggilan agama, memelihara diri dari kejahatan dan kerusakan,

4. Menumbuhkan kesungguhan untuk bertanggung jawab menerima hak serta kewajiban, juga bersungguh-sungguh untuk memperoleh harta kekayaan yang halal, serta

5. Membangun rumah tangga untuk membentuk masyarakat yang tentram atas dasar cinta dan kasih sayang. Perkawinan juga bertujuan untuk membentuk perjanjian (suci) antara seorang pria dan seorang wanita, yang mempunyai segi-segi Perdata di

${ }^{13}$ Qodariah Barkah, Pemikiran Fiqh M. Quraish Shihab dalam Tafsir al-Mishbah, (Palembang, 2006), hal. 16.

${ }^{14}$ Soemiyati, SH, Op.Cit., hal.12. 
antaranya adalah kesukarelaan, persetujuan kedua belah pihak, kebebasan memilih dan darurat. ${ }^{\text {s }}$

Hal yang sama dijelaskan oleh Abdullah Nasikh 'Ulwan, motif syariat Islam memerintahkan untuk melakukan pernikahan adalah dengan tujuan untuk:

1. Melestarikan keturunan,

2. Memelihara nasab (status),

3. Sebagai media pembentukkan rumah tangga ideal dan pendidikan anak,

4. Membebaskan masyarakat dari berbagai penyakit,

5. Memperoleh ketenangan jiwa dan spiritual, dan

6. Menumbuhkan kasih sayang orang tua kepada anak. ${ }^{16}$

Penjelasan di atas dapat dipahami bahwa, begitu mulianya Hukum Allah SWT, yang menyeru kepada hamba-Nya untuk bersegera menikah, dan menjauhi zina, guna menata kehidupan yang penuh Rahmat.

Syari'at mewajibkan kepada suami untuk memenuhi kebutuhan istrinya yang berupa kebutuhan material seperti nafkah, pakaian, tempat tinggal, pengobatan dan sebagainya, sesuai dengan kondisi masing- masing, atau seperti yang dikatakan oleh Al Qur'an "bilma'ruf” (menurut cara yang ma'ruf/ patut). Namun, Syari'at tidak pernah melupakan akan kebutuhankebutuhan spiritual manusia yang tidaklah bernama manusia kecuali dengan adanya kebutuhan-kebutuhan tersebut, sebagaimana kata seorang pujangga kuno: "Maka karena jiwamu itulah engkau sebagai manusia, bukan cuma dengan badanmu." Bahkan Al Qur'an menyebut perkawinan ini sebagai salah satu ayat diantara ayat-ayat Allah di alam semesta dan salah satu nikmat yang diberikan-Nya kepada hamba-hamba-Nya yang beriman dan taat kepada-Nya. ${ }^{17}$

${ }^{15}$ At Tihami AM dan Sohari Sahrani, Op.Cit., hal. 15.

${ }^{16}$ Abdullah Nasih 'Ulwan, Perkawinan Masalah Orang Muda, Orang Tua, dan Negara. Jakarta: Gema Insani Pers, 2002, hal. 11.

${ }^{17} \mathrm{http} / / /$ blogkokoronotomo.blogspot.com/2008/08/hak-istri-terhadap-suami.html, tanggal akses 20 Juni 2017. 
Kehidupan berkeluarga juga perlu dipahami, bahwa di dalamnya ada hak-hak dan kewajiban suami istri. Sebelum hak-hak suami istri diuraikan, maka suami-istri harus memiliki rasa sebagai berikut agar keluarga menggapai keluarga bahagia:

1. Amanah, masing-masing suami-istri harus bersikap amanah terhadap pasangannya, dan tidak mengkhianatinya sedikit atau banyak, karena suami istri adalah laksana dua mitra dimana pada keduanya harus ada sifat amanah, saling menasihati, jujur, dan ikhlas dalam semua urusan pribadi keduanya, dan urusan umum keduanya.

2. Cinta Kasih, artinya masing-masing suami-istri harus memberikan cinta kasih yang tulus kepada pasangannya sepanjang hidupnya.

Saling Percaya, artinya masing-masing suami-istri harus mempercayai pasangannya, dan tidak boleh meragukan kejujurannya, nasihatnya, dan keikhlasannya. Pernyatan implisit dari UU Nomor 1 Tahun 1974 tentang perkawinan diulangi dan dinyatakan secara eksplisit dalam KHI yang disebarluaskan dengan Inpres Nomor 1 Tahun 1991. Dalam KHI terdapat bab khusus mengenai kawin hamil, yaitu Bab VII Pasal 53 ayat (1), (2), dan (3).

1. Seorang wanita hamil di luar nikah, dapat di kawinkan dengan pria yang menghamilinya.

2. Perkawinan dengan wanita hamil yang disebut pada ayat (1) dapat dilangsungkan tanpa menunggu lebih dahulu kelahiran anaknya.

3. Dengan dilangsungkannya perkawinan pada saat wanita hamil, tidak diperlukan perkawinan ulang setelah anak yang dikandung lahir.

Dalam Kompilasi Hukum Islam ditetapkan bahwa seorang wanita hamil di luar nikah, dapat dikawinkan dengan laki-laki yang menghamilinya, tanpa harus menunggu kelahiran anak yang ada dalam kandungannya terlebih dahulu. Pernikahan yang dilangsungkan pada saat hamil tidak diperlukan lagi perkawinan ulang setelah anak yang dikandungnya lahir.

Secara langsung dapat dipahami bahwa pasal 53 Kompilasi Hukum Islam yang terdiri dari 3 ayat tersebut, lebih menghormati wanitanya. Ungkapan yang dapat kita pahami tentang wanita adalah sebagai mata air 
kebahagiaan dalam kehidupan, sumber kasih sayang dan kelembutan, wanita adalah tiang dan rahasia kesuksesan seorang laki-laki dalam kehidupan. Wanita dapat membangkitkan keberanian dan semangatnya, menanamkan rasa cinta dan tanggung jawab terhadap pekerjaan, melahirkan sifat sabar dan tabah, melenyapkan rasa lelah dan letih, membuat tabiatnya yang halus, serta perasaannya halus.

Dari ungkapan di atas, maka tiga ayat yang terkandung di dalam pasal 53 Kompilasi Hukum Islam tersebut adalah bentuk aturan Hukum yang mengatur wanita hamil di luar nikah jika terjadi pernikahan. Dari ketiga ayat pada Kompilasi Hukum Islam Pasal 53 di atas, dapat memberikan gambaran bahwa:

1. Yang bertanggung jawab dalam menikahi wanita hamil adalah laki-laki yang menghamilinya, berkaitan dengan nasab anak yang ada dalam kandungannya.

2. Agar tidak dijadikan hal yang bisa menikahi wanita hamil di luar nikah, maka harus menunggu wanita itu melahirkan dan mensucikan dirinya dari nifas. Sebab, pernikahan adalah suci.

3. Pernikahan tidak dapat diulang. Dengan maksud agar pernikahan tidak ternodai..$^{18}$

\section{B. METODE PENELITIAN}

Jenis penelitian ini adalah penelitian kualitatif yang dilakukan di lapangan. Penelitian ini bersifat deskriptif-analitis. Setelah data terkumpul akan dideskripsikan terlebih dahulu seputar masalah pernikahan secara umum. Kemudian dilanjutkan dengan pembahasan pada pokok masalah tentang pernikahan wanita hamil karena zina dan terakhir akan dianalisis ketentuan yang terdapat dalam Kompilasi Hukum Islam berkaitan dengan pernikahan tersebut. Pendekatan yang ditempuh dalam penelitian ini adalah pendekatan yuridis-normatif-sosiologis. Subyek penelitian dalam karya ilmiah ini adalah Kepala dan Penghulu KUA Kecamatan Masaran, serta beberapa pelaku kasus pernikahan wanita hamil di Kecamatan Masaran

18 http://alIslamu.com/index.php?Itemid=5\&id=147\&option=com_content\&task=view, tanggal akses 20 Juni 2017 
Sragen.

\section{HASIL DAN PEMBAHASAN}

Berdasarkan hasil wawancara dengan Kepala KUA Kec. Masaran diperoleh keterangan bahwa dari tahun ke tahun prosentase pernikahan wanita hamil diluar nikah semakin meningkat yang sangat menghawatirkan. Dan pelaku pernikahan wanita hamil ini didominasi usia yang sangat muda dan masih bersekolah.

Ada dua hal faktor yang mempengaruhi pernikahan wanita hamil ini, yang pertama faktor individual yaitu lemahnya mental spritual dan faktor yang kedua faktor lingkungan yaitu lemahnya kontrol orang tua dan perkembangan IPTEK yang berdampak negatif. Dari hasil wawancara prosentase yang menunjukkan faktor utama dalam mempengaruhi penyebab terjadinya kehamilan di luar nikah di Wilayah KUA Masaran Sragen adalah faktor lingkungan. Pengaruh lingkungan adalah faktor utama yang menyebabkan timbulnya penyimpangan seksual, sehingga mengakibatkan kehamilan sebelum menikah.

Di antara faktor lingkungan adalah orang tua, anggapan yang keliru dari orang tua yang mementingkan pekerjaan mereka, mereka tidak perduli dengan perkembangan anak, dimana dan dengan siapa saja mereka bergaul. Sehingga mengakibatkan kurangnya kontrol terhadap anak, yang mengakibatkan anak bergaul bebas dan melakukan apa yang mereka inginkan karena tidak ada peraturan dari orang tua mereka. Dalam hal ini peran orang tua sangat diharapkan guna mengurangi pergaulan bebas yang berdampak pada kehamilan di luar nikah. Orang tua harus mampu mengontrol pergaulan anak, dan mengetahui karakter anak jika diluar rumah.

Faktor lingkungan yang kedua yaitu lingkungan, salahnya pergaulan bebas yang terjadi sekarang ini begitu juga yang terjadi di wilayah Kecamatan Masaran. Acara-acara di televisi, tabloid, majalah, dan internet dan media-media lainnya merangsang untuk mencoba dan menyalurkan ke hal yang haram.

Kurangnya penanaman akhlaq, lemahnya iman serta tidak ada kontrol dari orangtua serta bergaul pada tempat yang salah dilengkapi dengan perkembangan IPTEK, maraknya internet yang bisa mengakses ke hal-hal yang negatif mengakibatkan para remaja melakukan hubungan suami 
istri, yang berakibat pada kehamilan dan pernikahan dini.

Peran orang tua, dan lingkungan diharapkan mampu mengurangi angka kehamilan sebelum pernikahan. Dan dari pihak KUA Kec. Masaran telah melakukan penyuluhan-penyuluhan pada waktu suscatin maupun pengajian-pengajian di wilayah Kec. Masaran.

Pelaksanaan pernikahan wanita hamil yang terjadi di KUA Kec. Masaran Sragen pada umumnya dilakukan dengan pria atau laki-laki yang menghamilinya. Belum pernah terjadi pernikahan wanita hamil diluar, yang menikahi adalah pria yang bukan menghamilinya. ${ }^{9}$

Adapun prosedur pelaksanaan pernikahan di KUA Kecamatan Masaran adalah apabila syarat-syarat dan rukunnya telah terpenuhi, perkawinan tersebut dapat dilaksanakan. Sebelum pernikahan dilangsungkan, calon mempelai juga diharuskan memenuhi syarat-syarat formal sebagai kelengkapan surat-surat yang diperlukan yaitu:

1. Surat Keterangan untuk nikah dari Kepala Desa/ Lurah (model N)

2. Kutipan Akte Kelahiran/ Surat kenal lahir/ Surat keterangan asal usul (model N2).

3. Surat persetujuan dari kedua mempelai (model N3)

4. Surat keterangan tentang orang tua dari Kepala Desa/ Lurah (model N4)

5. Surat izin dari orang tua bagi calon pengantin yang belum mencapai umur 21 tahun (model N5)

6. Surat izin dari Pengadilan Agama bagi calon pengantin yang belum mencapai umur 19 tahun (laki-laki) dan 16 tahun (perempuan)

7. Akta Cerai bagi janda/ duda, atau surat keterangan kematian bagi janda/ duda yang ditinggal mati

8. Pemberitahuan kehendak nikah (model N7).

Selain syarat diatas calon pengantin harus menyertakan fotocopi Kartu Tanda Penduduk (KTP), Kartu Keluarga (KK), Ijazah pendidikan Juni 2017

${ }^{19}$ Hasil Wawancara dengan Bapak Drs. Sakimin, Kepala KUA Kec. Masaran pada tanggal 28 
terakhir, Foto $2 \times 3$ sebanyak 4 lembar, surat pernyataan masih jejaka/perawan bagi mereka yang telah berumur lebih dari 30 tahun. Dan juga surat keterangan telah melakukan test kesehatan dari Puskesmas setempat (Imunisasi).

Seperti yang penyusun uraikan di atas bahwa prosedur pelaksanaan pernikahan wanita hamil adalah sama dengan prosedur pelaksanaan pernikahan pada umumnya demikian juga pelaksanaan nikah hamil di KUA Kecamatan Masaran dalam pencatatanya oleh Pegawai Pencatat Nikah (PPN), nikah hamil ini tidak diberikan catatan khususkarena tidak ada aturan tentang hal itu.

Pernikahan wanita hamil dapat diketahui dengan memeriksa berkas nikahnya, tertera dalam surat keterangan kesehatan (suntik TT) dari dokter yang biasanya diberikan oleh puskesmas setempat dimana mempelai wanita tinggal. Hal ini bertujuaan untuk memberikan keterangan kondisi kesehatan bagi calon pengantin yang akan melangsungkan perkawinan. Salah satu isi dalam surat ini adalah hasil pemeriksaan urine calon mempelai wanita negatif atau positif. Jika tercatat positif berarti calon mempelai wanita telah hamil sebelum pelaksanaan nikah. Selain itu kehamilan pada calon mempelai dapat diketahui dengan bentuk fisik atau perut yang membesar.

Penghulu, pegawai yang bertugas untuk memeriksa berkas dan kemudian mendaftar pernikahan adalah pihak yang pertama mengetahui apakah calon istri telah hamil atau masih benar-benar perawan. Apabila menjumpai surat keterangan kesehatan ada tanda positif, penghulu akan menanyakan lebih lanjut apakah benar calon istri telah hamil, pertanyaan berikutnya siapa laki-laki yang telah menghamilinya dan berapa usia kandungan calon mempelai wanita.

Jika calon mempelai perempuan telah mengakui kehamilannya dan benar bahwa laki-laki yang akan menikahinya adalah laki-laki yang telah menghamilinya, maka mereka atau kedua calon mempelai tersebut harus membuat surat pernyataan. Calon mempelai wanita membuat surat pernyataan telah dihamili, dan calon mempelai laki-laki membuat surat penyataan telah menghamili, ditandatangani keduanya diatas materai 6.000. Setelah semua syarat terpenuhi, Penghulu mendaftar perikahan mereka. Kemudian dilakukan pemeriksaan lebih lanjut mengenai data-data atau berkas pernikahan mereka. 
Kepala KUA atau penghulu waktu memberikan kursus pengantin (suscatin), penasehatan sebelum pernikahan dilaksanakan, kepada calon mempelai pernikahan wanita hamil akan dituntun untuk melakukan taubat dengan mengucap istighfar dan berjanji tidak akan berbuat maksiat lagi, tidak boleh melakukan hubungan suami istri lagi sebelum ijab qobul dilaksanakan. Dan kepada bapak sebagai orangtua maupun yang akan bertindak sebagai wali nikahnya kelak, supaya mendampingi anaknya yang telah berbuat dosa untuk segera bertaubat, tidak mengulangi maksiat dengan tidak membolehkan keduanya tidak tinggal serumah. Secara syar'i sudah terpenuhi dan juga telah sesuai dengan ketentuan atau Undang-undang yang berlaku, dengan demikian pernikahan wanita hamil diluar nikah dapat dilaksanakan.

Sesuai dengan pasal 2 undang-undang No. 1 tahun 1974, bahwa tiaptiap perkawinan harus dicatatkan. Perkawinan itu sah apabila dilakukan menurut hukum dan kepercayaan masing-masing. Di Indonesia pencatatan perkawinan dilakukan oleh dua lembaga resmi yaitu Kantor Urusan Agama untuk yang beragama Islam dan Kantor Catatan Sipil untuk yang bukan beragama Islam.

Pencatatan pernikahan yang dilakukan oleh KUA Kecamatan berpedoman kepada peraturan perundang-undangan yang berlaku antara lain : Undang-undang No.1 Tahun 1974 tentang Perkawinan, Instruksi Presiden No. 1 Tahun 1991 tentang Penyebarluasan Kompilasi Hukum Islam, Keputusan Menteri Agama No. 477 Tahun 2007 tentang Pencatatan Pernikahan dan masih banyak lagi.

Sebagaimana dikemukakan pada bab sebelumnya, khusus mengenai pernikahan wanita hamil diatur dalam Kompilasi Hukum Islam terdapat pada Bab VIII pasal 53. Kompilasi Hukum Islam yang telah disepakati oleh para ulama diIndonesia menyatakan tentang kebolehan pernikahan wanita hamil sepanjang dilakukan dengan pria yang menghamilinya, sebagaimana yang terkandung dalam KHI pasal 53 ayat (1). Demikian pula yang terjadi di KUA Kecamatan Masaran terhadap kasus pernikahan wanita hamil diluar nikah, yang membolehkan berlangsungnya pernikahan ini. Wanita yang telah hamil sebelum pernikahan dilangsungkan dapat mengajukan permohonan pernikahan ke KUA, sepanjang dengan laki-laki yang telah menghamilinya. 
Prosedur pelaksanaan pernikahan wanita hamil adalah sama dengan prosedur pelaksanaan pernikahan pada umumnya demikian juga pelaksanaan nikah hamil di KUA Kecamatan Masaran dalam pencatatanya oleh Pegawai Pencatat Nikah (PPN), nikah hamil ini tidak diberikan catatan khusus karena tidak ada aturan tentang hal itu. Ketika semua syarat pernikahan sudah terpenuhi artinya sudah tidak ada halangan atau kekurangan syarat, maka pernikahan segera dilaksanakan sesuai dengan permintaan wali atau calon pengantin. Pelaksanaan pernikahan wanita hamil diluar nikah di KUA Kec. Masaran tidak menunggu kelahiran anak dalam kandungan sang calon mempelai wanita berapapun usia kandungannya. Dan selanjutnya pihak KUA tidak mengadakan pernikahan ulang setelah anaknya lahir, hal ini berpedoman pada ayat (3) Kompilasi Hukum Islam pasal 53. Sehingga pelaksanaan pernikahan wanita hamil di luar nikah yang terjadi di KUA Kec. Masaran telah berdasar dan dengan aturan hukum atau perundang-undangan yang berlaku, khususnya sebagaimana aturan yang tertuang dalam Kompilasi Hukum Islam Pasal 53.

Dari banyaknya Hukum di Indonesia, memiliki kapasitas dan wilayah-wilayahnya sendiri guna penertiban dan menjadikan kehidupan bermasyarakat, berbangsa dan bernegara menjadi aman, damai sebagaimana yang diharapkan. Sebelum kepada isi pasal 53 Kompilasi Hukum Islam tentang pernikahan wanita hamil di luar nikah dan penjelasannya, disini akan diuraikan terlebih dahulu dari sebuah hadits Rasulullah SAW, yang diriwayatkan oleh Muslim, tentang had zina.

Dari Ubadah bin Shamit ra. dia berkata: Rasulullah SAW bersabda: "Ambillah dariku, ambillah dariku. Sungguh Allah telah menjadikan jalan bagi mereka; perempuan lajang yang berzina dengan perempuan lajang (sanksinya) adalah dera seratus kali dan diasingkan selama satu tahun, sedangkan perempuan janda yang berzina dengan laki-laki duda (sanksinya) adalah dera seratus kali dan rajam". (HR. Muslim)

Hadits di atas menjelaskan hukuman bagi perilaku zina, sebagaimana oleh Abu Hanifah dan para pengikutnya berpendapat tentang hal ini bahwa pengasingan, dalam hukuman zina tidak wajib dilakukan. Mereka hanya membolehkan saja untuk menyatukan hukuman jilid dengan pengasingan apabila pelaksanaannya membawa kemaslahatan tertentu.

Pandangan ulama empat mahzab, yakni memandang pernikahan wanita hamil atau zina adalah dari perihal anak dalam kandungannya, yaitu 
bahwa anak zina sama hukumnya dengan anak hasil mula'anah (anak li'an) dalam kaitannya dengan masalah hak waris-mewarisi antara dirinya dengan ayahnya, dan adanya hak mewarisi antara dia dengan ibunya.

Dengan demikian, muncullah pasal 53 Kompilasi Hukum Islam yang akan memberikan penjelasan tentang masalah di atas "Pernikahan wanita hamil". Adapun isi pasal 53 Kompilasi Hukum Islam "Kawin Hamil" adalah sebagai berikut:

1. Seorang wanita hamil di luar nikah, dapat dikawinkan dengan pria yang menghamilinya.

2. Pernikahan dengan wanita hamil yang disebut pada ayat (1) dapat dilangsungkan tanpa menunggu lebih dahulu kelahiran anaknya.

3. Dengan dilangsungkannya pernikahan pada saat wanita hamil, tidak diperlukan pernikahan ulang setelah anak yang dikandung lahir.

Secara langsung dapat dipahami bahwa pasal 53 Kompilasi Hukum Islam yang terdiri dari 3 ayat tersebut, lebih menghormati wanitanya. Ungkapan yang dapat kita pahami tentang wanita adalah sebagai mata air kebahagiaan dalam kehidupan, sumber kasih sayang dan kelembutan, wanita adalah tiang dan rahasia kesuksesan seorang laki-laki dalam kehidupan. Wanita dapat membangkitkan keberanian dan semangatnya, menanamkan rasa cinta dan tanggung jawab terhadap pekerjaan, melahirkan sifat sabar dan tabah, melenyapkan rasa lelah dan letih, membuat tabiatnya yang halus, serta perasaannya halus.

Dari ungkapan di atas, maka tiga ayat yang terkandung di dalam pasal 53 Kompilasi Hukum Islam tersebut adalah bentuk aturan Hukum yang mengatur wanita hamil di luar nikah jika terjadi pernikahan. Hal ini lah yang menjadi dasar KUA Kecamatan Masaran Sragen berani melaksanaan pernikahan wanita hamil sebelum nikah.

Pada ayat 1 di atas menyatakan bahwa "seorang wanita hamil di luar nikah, dapat di kawinkan dengan pria yang menghamilinya." Dapat dijelaskan: dalam Hukum pun akan membenarkan jika yang harus bertanggung jawab untuk menikahinya adalah lelaki yang menghamilinya. Berikut dalam bukunya Ghazaly, Fiqh Munakahat dengan pendapat para 
ulama berdasarkan hukum yang telah pernah diterapkan oleh sahabat Nabi, yaitu:

1. Ketika Jabir bin Abdillah ditanya tentang kebolehan mengawinkan orang yang telah berzina, beliau berkata: "Boleh mengawinkannya, asal keduanya telah bertaubat dan memperbaiki sifat-sifatnya".

2. Seorang laki-laki tua menyatakan keberatannya kepada khalifah Abu Bakar dan berkata: ya Amirul Mukminin, putriku telah dicampuri oleh tamuku, dan aku inginkan agar keduanya dikawinkan. Ketika itu khalifah memerintahkan kepada sahabat lain untuk melakukan hukuman dera (cambuk) kemudian dikawinkannya.

Selain itu dijelaskan pula bahwa fukaha berselisih pendapat tentang menikahi wanita hamil di luar nikah (zina), ke dalam tiga pendapat:

Pendapat pertama: Zina tidak memiliki bagian dalam kewajiban beri'iddah. Sama saja apakah dia mempunyai suami atau tidak. Jika dia mempunyai suami, maka halal bagi suaminya untuk menyetubuhinya langsung. Dan jika dia tidak mempunyai suami, maka boleh bagi laki-laki yang berzina dengannya atau orang lain untuk menikahinya, baik dia hamil atau tidak. Hanya saja menyetubuhinya dalam keadaan hamil hukumnya makruh, sampai dia melahirkan. Ini adalah pendapat para ulama mazhab Syafi'i.

Pendapat kedua: Jika wanita yang dizinai tidak hamil, maka laki-laki yang berzina dengannya atau laki-laki lain boleh menikahinya, dan dia tidak wajib ber'iddah. Ini adalah pendapat yang disepakati dalam mahzab Hanafi. Sedangkan jika wanita yang dizinai hamil, maka dia boleh dinikahi menurut Abu Hanifah dan Muhammad, tapi tidak boleh disetubuhi sampai melahirkan.

Pendapat ketiga: Wanita yang berzina tidak boleh dinikahi. Dan dia wajib ber'iddah dengan waktu yang ditetapkan jika dia tidak hamil, dan dengan melahirkan kandungannya jika dia hamil. Jika dia memiliki suami, maka suaminya tidak boleh menyetubuhinya sampai 'iddahnya habis. Ini adalah pendapat Rabi'ah, ats-Tsauri, al-Auzai, dan Ishaq. Dan ini adalah mahzab Maliki dan Hanbali. 
Jika terjadi pernikahan dengan orang yang bukan mengahamilinya, dijelaskan kembali oleh Ghazali yakni:

1. Imam Abu Yusuf mengatakan, keduanya tidak boleh dikawinkan. Sebab bila dikawinkan perkawinannya batal (fasid). Maksudnya adalah, tidak pantas seorang pria yang beriman kawin dengan seorang wanita yang berzina. Demikian pula sebaliknya, wanita yang beriman tidak pantas kawin dengan pria yang berzina.

2. Imam Muhammad bin Al-Hasan Al-Syaibani mengatakan bahwa perkawinannya itu sah, tetapi haram baginya bercampur, selama bayi yang dikandungnya belum lahir.

3. Imam Abu Hanifah dan Imam Syafi'i berpendapat bahwa perkawinan itu dipandang sah, karena tidak terikat dengan perkawinan orang lain (tidak ada masa 'iddah). Wanita itu boleh juga dicampuri, karena tidak mungkin nasab (keturunan) bayi yang dikandung itu ternodai oleh sperma suaminya. Sedangkan bayi tersebut bukan keturunan orang yang mengawini ibunya itu (anak di luar nikah).

Berikut pada ayat 2 menyatakan bahwa "Perkawinan dengan wanita hamil yang disebut pada ayat (1) dapat dilangsungkan tanpa menunggu lebih dahulu kelahiran anaknya." Ayat 2 ini melindungi terbukanya aib dan melindungi status anak. Namun dengan demikian, Ghazaly memandang perihal status anak adalah sebagai anak zina, bila pria yang mengawini ibunya itu bukan pria yang menghamilinya. Namun, bila pria yang mengawini ibunya itu, pria yang menghamilinya, maka: Pertama, Bayi itu termasuk anak zina, bila ibunya dikawini setelah usiakandungannya berumur 4 bulan ke atas. Bila kurang 4 bulan, maka bayi tersebut adalah anak suaminya yang sah. Kedua, Bayi itu termasuk anak zina, karena anak itu adalah anak di luar nikah, walaupun dilihat dari segi bahasa bahwa anak itu adalah anaknya, karena hasil dari sperma dan ovum bapak dari ibunya itu.

Hal lain diungkapkan pula oleh para ulama mazhab yang sependapat bahwa dalam hal perkawinan yang sah, bila seorang perempuan melahirkan anak, anak itu bisa dihubungkan nasabnya kepada suaminya. Akan tetapi, untuk dapat menghubungkan nasab anak kepada ayahnya, terdapat beberapa syarat yang harus dipenuhi, diantaranya: anak tersebut dilahirkan setelah berlalunya waktu enam bulan sejak terjadinya akad nikah (menurut 
Hanafiyah) atau enam bulan sejak terjadinya persetubuhan suami istri (menurut mayoritas ulama mazhab). Bila anak lahir kurang dari enam bulan dari waktu akad atau dari persetubuhan suami istri, anak itu tidak bisa dihubungkan nasabnya kepada suami wanita yang melahirkannya itu. Hal ini bisa menjadi petunjuk bahwa kehamilan telah terjadi sebelum terjadinya perkawinan, kecuali jika suami mengakui bahwa anak yang dilahirkan itu adalah anaknya dan mengakui pula dirinyalah yang mehamili wanita itu sebelum ia menikahinya.

Sedangkan pada ayat 3 menyatakan bahwa "Dengan dilangsungkannya perkawinan pada saat wanita hamil, tidak diperlukan perkawinan ulang setelah anak yang di kandung lahir." Jika dilihat dari sisi pernikahannya, maka pernikahan itu hanya dilakukan sekali saja dengan orang yang sama. Artinya tidak dapat diulang lagi. Begitupun, Al-Khatib dalam bukunya Fikih Wanita Hamil fukaha berpendapat bahwa: Wanita yang berzina tidak boleh dinikahi. Dan dia wajib ber'iddah dengan waktu yang ditetapkan jika dia tidak hamil, dan dengan melahirkan kandungannya jika dia hamil.

Pernyataan fukaha di atas pada ayat 3 ini, menjelaskan adanya penundaan nikah hingga bayi yang dikandung wanita yang di zinai atau bukan, lahir terlebih dahulu dan menunggu masa 'iddah, setelah itu boleh dinikahkan. Ini artinya, wanita hamil yang diatur dalam pasal 53 Kompilasi Hukum Islam "Kawin Hamil" terlindungi. Hal lain dapat dikatakan sebagai penutup aib, dan pemberian kepastian hukum. Namun, penjelasan pasal 53 tersebut, yang diharapkan bukanlah asumsi masyarakat yang mengetahui hanya sebatas itu saja, yaitu penutup aib. Hal terbesar lainnya yang harus dipahami dalam penjelasan pasal ini adalah tentang kesucian daripada nikah itu sendiri, bukan terhadap perlindungan dari segala bentuk perzinahan hingga kehamilan terjadi.

Dari ketiga ayat pada Kompilasi Hukum Islam Pasal 53 di atas, hal demikian yang dilakukan oleh KUA Kec. Masaran Sragen terhadap pernikahan wanita hamil dapat memberikan gambaran bahwa:

1. Yang bertanggung jawab dalam menikahi wanita hamil adalah laki-laki yang menghamilinya, berkaitan dengan nasab anak yang ada dalam kandungannya. 
2. Pernikahan tidak dapat diulang. Dengan maksud agar pernikahan tidak ternodai.

Secara jelas, kita ketahui bahwa pasal 53 Kompilasi Hukum Islam tentang Pernikahan Wanita Hamil di Luar Nikah ini membolehkan pernikahan wanita hamil tersebut. Tanpa terbantahkan dengan apapun juga. Hal ini lah yang menjadi dasar pelaksanaan pernikahan wanita hamil di KUA Kec. Masaran Sragen. Namun, pengertian lainnya, penjelasan pasal 53 Kompilasi Hukum Islam tentang "kawin hamil" atau pernikahan wanita hamil di luar nikah ini, boleh tidaknya dilihat terlebih dahulu sebabsebabnya. Lebih kepada mudharat atau manfaat jika terjadi pernikahan ini. Karena Islam tidak gegabah dalam menentukan suatu hukum. Lebih dapat dipahami, bahwa pasal 53 Kompilasi Hukum Islam, seharusnya memberikan penjelasan bahwa terdapat sanksi-sanksi sebelum adanya pernikahan dengan wanita hamil terhadap wanita hamil tersebut dan laki-laki yang menghamilinya.

Dari uraian di atas, dengan maksud dan tujuan dari permasalahan pernikahan hamil di luar nikah yang terjadi di KUA Kec. Masaran Sragen telah sesuai dengan apa yang terkandung dalam pasal 53 Kompilasi Hukum Islam tentang "Kawin Hamil”, serta tidak melanggar syariat.

\section{KESIMPULAN}

Pelaksanaan pernikahan wanita hamil yang terjadi di KUA Kecamatan Masaran Sragen Tahun 2017 adalah sama dengan ketentuan pernikahan pada umumnya atau pada mestinya, sehingga tidak ada perbedaan antara pelaksanaan pernikahan wanita yang telah hamil dengan pernikahan wanita yang belum hamil. Tinjauan Kompilasi Hukum Islam pasal 53 terhadap pernikahan wanita hamil di luar nikah di KUA Kec. Masaran Kab.Sragen sudah mengikuti aturan yang berlaku dan tidak bertentangan dengan isi surat An-nur ayat 3 karena keduanya berstatus sebagai pezina, bahwa pasal 53 Kompilasi Hukum Islam tentang Pernikahan Wanita Hamil di Luar Nikah ini membolehkan pernikahan wanita hamil tersebut. 


\section{REFERENSI}

Abdullah Nasikh 'Ulwan, Perkawinan Masalah Orang Muda, Orang Tua, dan Negara. Jakarta: Gema Insani Pers, 2002

At-Tihami, M.A, dan Sohari Sahrani, Fikih Munakahat Kajian Fikih Lengkap, (Jakarta: Raja Wali Pers, 2008)

D.Y. Witanto, Hukum Keluarga Hak dan Kedudukan Anak Luar Kawin, (Jakarta: Prestasi Pustaka, 2012)

Dirjen Bimas Islam RI, Himpunan Peraturan Perundang-Undangan Perkawinan,(Jakarta: Depag, 2010)

Ibrahim Hosen, Fiqh Perbandingan, (Jakarta: Ihya Ulumiddin Indonesia, 1971)

Kamal Mukhtar, Asas-asas Hukum Islam Tentang Perkawinan, (Jakarta: Bulan Bintang, 1993)

M. Yahya Harahap, Peradilan Agama dan Kompilasi Hukum Islam Dalam Tata Hukum Indonesia, (Yogyakarta: UII Press, 1993)

Mahmud Yunus, Kamus Bahasa Arab-Indonesia, (Jakarta: Hidakarya Agung, 1990)

Mawardi Labay el-Sulthani, Tidak Usah Takut Syari'at Islam, (Jakarta: Al Mawardi Prima, 2002)

Muhammad Jawad Mughniyah, Fiqh Lima Mahzab, (Jakarta: Lentera, 2007)

Qodariah Barkah, Pemikiran Fiqh M. Quraish Shihab dalam Tafsir alMishbah, (Palembang, 2006)

Said Agil Husin al-Munawar, Hukum Islam, (Jakarta: Penamadani, 2005)

Soemiyati, Hukum Perkawinan Islam dan Undang-Undang Perkawinan, (Yogyakarta: Liberty, 1982)

TaufikRahman, Hadis-Hadis Hukum, (Bandung: Pustaka Setia, 2000) 